\title{
ORGANIZATION ON THE EUROPEAN UNION IN THE SPHERE OF PENAL PREPARATION
}

\author{
Marin Petkov ${ }^{1}$ and Dragomir Krastev ${ }^{2}$, \\ ${ }^{1}$ Assoc. Professor, Ph.D., National Military University, Veliko Tarnovo, Bulgaria, \\ marin_5kov@abv.bg \\ ${ }^{2}$ Assoc. Professor, Ph.D., National Military University, Veliko Tarnovo, Bulgaria, \\ drago.krastev@gmail.com
}

\begin{abstract}
The interaction and exchange of information between the national police of the organization on Schengen territory is much more than the scope of the subordination from the international organization for police cooperation, the co-ordination of the point-by-point contact in the framework of a nationally competent structure on the line for international police cooperation. They come along as a decisive sign on the counteraction tasks to the internationality of the world

With the development of the international police cooperation that will introduce the new stuff for the interaction, it will provide additional opportunities at the national level to the competent authority for the purpose of public administration and regional security, the guardianship of the societies of the eds in the border zones and the counteraction to the accidents with the international element.
\end{abstract}

Keywords: penal preparation, Europol, Eurojust, security, crimes, police cooperation.

\section{INTRODUCTION}

Security and the fight against crime has always been a topical issue in European affairs, and mechanisms to develop cooperation between national authorities in this field date back to the late 1970s. Introduced on a purely intergovernmental basis in 1993 as part of the Third Pillar, police and judicial cooperation in criminal matters (PJCCM) has become one of the fastest growing domains of EU action. EU's activities in this field have also entailed an external dimension, through which the European Union (EU) sought to establish and deepen its cooperation with third countries and international organisations.

\section{ORGANIZATION ON THE EUROPEAN UNION IN THE SPHERE OF PENAL PREPARATION}

The EU's activities in criminal matters have been given a new impetus with the entry into force of the Lisbon Treaty. The latter consecrated as one of the objectives of the European Union (EU) ensuring „a high level of security through measures to prevent and combat crime" (Art. 67 (1) TFEU). It also abolished the pillar structure, thus subjecting EU criminal law instruments to the Community method (albeit with few exceptions), 
and granted the EU new competences to develop its activities in the field of law enforcement and criminal justice. The Lisbon Treaty also singled out the two EU agencies active in the field of PJCCM, Europol and Eurojust. These two agencies, which are working alongside the other EU specialised AFSJ agencies, 2 are the only EU AFSJ agencies whose mandates are defined in EU primary law (Articles 88 and 85 TFEU).

Europol and Eurojust thus deserve further attention. Given their role of supporting and strengthening cooperation between EU Member States in criminal matters, they constitute key actors for EU's internal security and combat against crime. They possess very complementary mandates and competences. Even though this may lead to overlaps and tensions between them, it also imply that their joint participation in a case often results in a strong added-value and increase the chances of a successful outcome. The two agencies are also taking part in the EU's efforts to promote cooperation in criminal matters with external partners, like other agencies, such as Frontex, do in their respective fields of competences. Europol and Eurojust have developed within their respective mandates tools and expertise that are crucial for the success of cross-border investigations and prosecutions, and which make them interesting partners from the perspective of third countries and international organisations. Both agencies have concluded agreements with external partners, forming the basis for diverse forms of cooperation.

The research objective is to assess the legal framework organising the mandate and work of Europol and Eurojust, and more particularly the provisions regulating their external activities in order to determine whether their constitutive instruments are appropriate to meet the challenges ahead. These challenges can be political, as the agencies remain relatively new actors, still in the process of gaining the trust of national (EU and non-EU) authorities, and are not necessarily perceived as potential partners by third countries. Similarly, a third country may prefer not to cooperate with the agencies, and instead to conclude bilateral cooperation agreements with individual Member States - the latter remaining the only ones possessing operational capabilities in the sense of deployable personnel and technical means. These challenges which focuses on the legal challenges encountered by the agencies when they develop their external activities. Even though both Europol and Eurojust are guided by their desire to ensure the efficiency and effectiveness of their cooperation with their external partners, their desire is somewhat constrained by two legal challenges:

They need to accommodate the diversity existing among both EU member States and third countries, while preventing a situation in which differentiation and variable geometry compromise smooth cooperation;

As EU agencies, they are bound by the respect for the rule of the law, the protection of fundamental rights, and data protection rules, enshrined in EU primary law and applicable in the EU's external relations (Art. 20 TEU). They need to strike a delicate balance between the effectiveness of their operational cooperation with external partners and the protection of fundamental rights.

Europol and Eurojust both pre-exist the Lisbon treaty, yet with this new instrument, the two agencies are for the first time mentioned in Articles 85 and 88 TFEU, and their roles and mandates are enshrined in EU primary law. The two agencies can be described as sister agencies involved in the fight against serious cross-border crime affecting two or more EU Member States.

Europol's mission is to "support and strengthen action by the Member States' police authorities and other law enforcement services and their mutual cooperation in preventing and combating serious crime affecting two or more Member States, terrorism and forms of crime which affect a common interest covered by a Union policy" (Art. 88 (1) TFEU). Europol was set up to gather police and law enforcement information from national authorities and to provide strategic and/or operational analyses on the basis of this information. It has been compared to a 'mega-search engine'. It also coordinates law enforcement authorities' actions, and may support operational activities with its mobile office, analysis in real-time of information gathered on actions days, forensic tools, etc.

Eurojust's mission is to "support and strengthen coordination and cooperation between national investigating and prosecuting authorities in relation to serious crime affecting two or more Member States or requiring a prosecution on common bases" (Art. 85 (1) TFEU). Eurojust is a 'facilitator' of judicial cooperation, which intervenes to smoothen the effective functioning of judicial cooperation instruments (such as the European Arrest Warrant), to resolve legal issues arising in complex cases (such as conflicts of jurisdiction) and/or to stimulate the coordination of judicial authorities. It has been compared to a 'control tower', whose members will intervene when they notice the need to investigate in a coordinated manner cross-border and/or complex cases. It is important to stress that none of these agencies possesses operational powers. Europol has no vocation of being a European $\mathrm{FBI}$ its members have never been enabled to perform investigative acts on the ground. Similarly, Eurojust has no vocation of becoming a European prosecutor, and cannot directly perform investigative or prosecution acts. Nevertheless, they play a key role in assisting national authorities, 
especially for the coordination of investigations and prosecutions of the multilateral dimension of criminal cases.

The evolution of the two agencies' legal frameworks follows parallel paths, as the Commission proposed back in 2013 two proposals for Regulations. Whereas the Regulation for Europol has been adopted in May 2016 and entered into force on May 1st 2017, the negotiations on the Regulation for Eurojust are not yet finalised. A general approach had been adopted by the Council in February 2015, and the negotiations had been put on hold, pending progresses in the negotiations of the regulation establishing the European Public Prosecutor's Office. The analysis of the future legal framework of Eurojust will thus be based on the text of the General Approach. However, given the recent adoption of the Regulation establishing the European Public Prosecutor's Office, the negotiations on the Eurojust regulation could reach their end soon These new legal instruments pursue several objectives. They not only "lisbonise” the functioning of the agencies, i.e. adapt it to the post-Lisbon Treaty legal framework, but they also give them new tools and competences to further support cross-border cooperation in criminal matters. Such evolution is to be welcomed especially considering the globalisation of crime, and the frequency and scale of crossborder criminal activities. Indeed, if the globalisation of our economies and societies has created economic growth and wellbeing, it has also given rise to massive opportunities for criminal enterprise and leads to the globalisation of crime. Criminals, working either in groups or in networks, operate across continents. Those involved in traditional cross-border criminal activities, such as trafficking in drugs or arms, may produce the illicit substances or weapons in one continent, traffic them across another and market them in a third. Yet, these patterns are also now present in "modern" criminal activities, such as cybercrime, a field in which criminals commit crime anonymously over the Internet, anywhere and anytime, regardless of physical location.

Criminal activities are thus very often limited neither to a single member State nor to the territory of the EU. Terrorism, cyber-crime, migrant smuggling or trafficking in human beings are often mentioned among the most severe transnational criminal threats, especially since they lead to serious violations to their victims' fundamental rights. These changes in the criminal landscape constitute new challenges for national law enforcement and judicial authorities. They increasingly have to investigate and prosecute cases with crossborder elements and links with neighbouring countries and/or more geographically distant countries. An effective cooperation in criminal matters is thus essential to ensure effective prosecution and conviction of criminals (and thus to ensure the dissuasive effect of criminal law), and to protect the fundamental rights of victims of crime. This necessity in turn impacts the EU and the EU criminal justice agencies Europol and Eurojust. Taking into account the above mentioned evolutions of the criminal landscape, the EU developed the external dimension of its Area of Freedom, Security and Justice, which mainly aims at serving the internal EU security policy by creating a secure external environment in order to combat illegal immigration, terrorism and organised crime. This has led to the emergence of a whole set of instruments, provisions and mechanisms aimed at favouring cross-border cooperation in criminal matters between the European Union, the national authorities of its Member States and its external partners (third countries as well as international organisations). Europol and Eurojust, as EU agencies, participated in this development of the external dimension of the AFSJ. The agencies have benefited from the possibility to develop their cooperation with external partners, notably on the basis of EU secondary law. Their external activities take different forms: the signature of cooperation agreements, allowing or denying the exchange of personal data, the appointment of liaison officers or contact points, or the appointment of liaison magistrates. In practice, even though they remain service providers to the national authorities, and are not automatically involved in all cross-border operations, the two agencies regularly publish press releases detailing the support they offered in cases investigated and prosecuted in cooperation with non-EU Members States. The two agencies are often perceived as the EU structures which come closest to an EU operational capability, which adds to their attractiveness as interlocutor for third countries.

Europol and Eurojust have thus become key players in the development and deepening of cross-border cooperation in criminal matters, not only between national authorities operating in EU Member States, but also between these authorities and those operating in third countries. Their importance has been acknowledged by the EU institutions and the Member States, which have - during the negotiations of the two Regulations - substantially amended the provisions on the agencies' cooperation with third countries and international organisations. These amendments have not only placed the agencies under the general legal framework applicable to the EU's external relations, but they have also introduced new provisions, such as those allowing the exchange of information under derogation clauses. They testify the importance given to the security and the effectiveness of international cooperation in criminal matters in a context where crime prevention sometimes requires real-time transfer of information. These changes are all the more relevant considering that the UK, a key Member State in the field of security, will soon become a third country to the $\mathrm{EU}$, and will rely on the legal framework governing Europol's and Eurojust's external cooperation to continue 
to cooperate with them.

\section{CONCLUSION}

In the current security context, the cooperation with third countries and international organisations is of crucial importance for the EU's objectives of preventing and combating crime. The issue will also be an important point of discussion during the Brexit negotiations, as once the United Kingdom will have withdrawn from the EU, new modalities of cooperation between British authorities and EU agencies will have to be identified. The current modalities of cooperation between Europol, Eurojust and their external partners, which have been analysed in this paper, may serve as a source of inspiration for the EU and UK negotiators. They also reveal the potential limits that may be faced in developing the future modalities of cooperation between the EU and the UK, and the need to reflect on developing specific modalities eventually drawing on the UK's status of former Member State. These issues are of crucial importance, since insufficient cooperation in criminal matters between the EU and the UK may reduce the safety of the people of the UK and of EU citizens.

The two agencies face challenges, starting with the need to accommodate diversity within and outside the European Union. However, their main challenge probably lies in the sensitivity of the exchange of data with third countries that are not bound by the EU norms on the protection of fundamental rights and data protection, and thus potentially entailing severe violations of fundamental rights. The two agencies are not the only actors faced with this challenge, which promises to test the effectiveness of crime prevention against legal considerations, prohibiting the processing of information when it has been obtained in violation of fundamental rights. In today's security reality, marked by regular terrorist attacks, some advocate for looser human rights standards, considering for instance that information preventing an attack shall be used, even though it may have been obtained through torture. In a European Union founded on the respect of the rule of law, such arguments are difficult to uphold. One can welcome in this regard the references in Europol's and Eurojust's regulations to the respect for data protection as a pre-requisite for the reception of personal data from third countries and the transfer of personal data to third countries. In addition, the mechanisms set up to hold both agencies accountable before democratically elected bodies and before judges shall be essential in this regard, in order to ensure that no red lines are crossed. As the Europol Regulation entered into force just a few months ago, and the Eurojust regulation is still under negotiations, it is still too early to provide a definitive answer on whether they are effective and sufficient, and a close attention will need to be paid to their practical implementation (Hristov, 2018a, pp.61-67; Hristov, Radulov, lliev, Andreeva, 2010a; Hristov, 2018b, pp. 183-186; Hristov, Ninov, 2018c, pp.316-323; Hristov, Naplatanova, 2018d, pp. 293-315; Hristov, 2017a, pp. 998-1004, Hristov, Georgiev, 2017b, , pp. 110 -113; Hristov, Georgiev, 2017c, , pp. 114-117; Hristov, Glushkov, 2018e, pp.582-588; Hristov, Glushkov, 2018f, pp. 187-193; Hristov, 2017d, pp. 821-829; Madanski, Georgiev, 2017e, pp. 4-13; Madanski, Georgiev, 2017f, pp. 43-51; Terziev, Madanski, Georgiev, 2017g pp. 748-753; Terziev, Madanski, Georgiev, 2017h pp. 743747; Terziev, Madanski, Georgiev, 2017i pp. 923-927; Terziev, Madanski, Georgiev, 2017j, pp. 1051-1055; Terziev, Nichev, Bankov, 2016a, s.189-196; Terziev, Nichev, Bankov, 2016b, s. s.116-134; Terziev, Nichev, Bankov, 2016c, pp.12-21; Terziev, Nichev, Bankov, 2016d, str.119-128; Terziev, Nichev, Bankov, 2016e, str.129-146; Terziev, Nichev, Bankov, 2016e, str.129-146; Terziev, Nichev, Bankov, 2016f, str. 144-185; Terziev, Nichev, Bankov, 2016f, str. 144-185; Terziev, Nichev, Bankov, 2016g, s.413-422; Terziev, Nichev, Bankov, 2016h, str.177-204; Nichev, 2017k, str. 121-128; Nichev, 2017l, pp. 129-135; Kanev, Terziev. 2017m; Kanev, Terziev, 2017n; Terziev, 2017o; Terziev, 2016i; Terziev, 2017p; Terziev, 2017q; Terziev, Vezieva, Arabska, 2016j; Terziev, Manolov, 2016k; Terziev, Minev, Sotirov, Ivanov, 2016I; Terziev, Kanev, 2017r; Terziev, Madanski, 2017s; Terziev, Madanski, 2017t; Terziev, Madanski, 2017u; Terziev, Madanski, Kanev, 2017v; Terziev, Madanski, Kanev, 2017w; Terziev, Madanski, Kanev, 2017x; Terziev, Madanski, Kanev, 2017y; Terziev, Madanski, Kanev, 2017z; Terziev, Nichev, 2016m; Terziev, Nichev, 2017).

\section{REFERENCE LIST}

Hristov, Neno. (2018a). Military Education as Possibility in Bulgaria. IJAEDU- International E-Journal of Advances in Education, Vol. IV, Issue 10, April 2018, pp.61-67.

Hristov, N., Radulov, I., Iliev, P., Andreeva, P. (2010a). Prioritization Methodology for Development of Required Operational Capabilities. RTO-MP-SAS-081, 2010. 
Hristov, Neno. (2018b). NATO Resilience, Deter and Professional Military Education. Proceedings of INTCESS 2018- 5th International Conference on Education and Social Sciences 5-7 February 2018Istanbul, Turkey, pp. 183-186.

Hristov, N, Ninov, M. (2018c). People's Character As a Prerequisite for the Albanian 'National Delay'. // 5th International Conference on Education, Social Sciences and Humanities, 2-4 July, 2018, ISBN: 978605-82433-3-0 316, pp.316-323.

Hristov, N, Naplatanova, G. (2018d). The Stereotypes of Military Towards Journalists and Work with Embedded Reporters in Missions and Operations Abroad. // 5th International Conference on Education, Social Sciences and Humanities, 2-4 July, 2018 - Dubai, ISBN: 978-605-82433-3-0, pp. 293-315.

Hristov, Neno. (2017a). Bulgarian Experience in the Development of Military Concepts. // IJASOSInternational E-Journal of Advances in Social Sciences, Vol. III, Issue 9, December 2017, pp. 9981004.

Hristov, N., Georgiev, M. (2017b). Offset implementation impact on technology transfer in Bulgaria. // International Scientific Journal "Internauka". Izdatel' OOO «Finansovaya Rada Ukrainy», Kiyev, № 10 (32), 2017, pp. 110 -113, ISSN 2520-2057 (Hristov, N., Georgiev, M. Offset implementation impact on technology transfer in Bulgaria. // International Scientific Journal "Internauka". Издатель ООО «Финансовая Рада Украины», Киев, № 10 (32), 2017, pp. 110 -113, ISSN 2520-2057).

Hristov, N., Georgiev, M. (2017c). Offset as an economic operation and a trade practice. // International Scientific Journal “Internauka”. Izdatel' OOO «Finansovaya Rada Ukrainy», Kiyev, № 10 (32), 2017, pp. 114-117, ISSN 2520-2057 (Hristov, N., Georgiev, M. Offset as an economic operation and a trade practice. // International Scientific Journal "Internauka”. Издатель ООО «Финансовая Рада Украины», Киев, № 10 (32), 2017, pp. 114-117, ISSN 2520-2057).

Hristov, N., Glushkov, P. (2018e). Comparative Analysis of the Management Activity Training Of the Cadets, Studying in the Logistic Specializations. // Proceedings of INTCESS2018- 5th International Conference on Education and Social Sciences 5-7 February 2018- Istanbul, Turkey, pp.582-588.

Hristov, N., Glushkov, P. (2018f). Some Aspects Regarding the Display of the Organizational Activity at Work of the Logistic Officers. // Proceedings of INTCESS2018- 5th International Conference on Education and Social Sciences 5-7 February 2018- Istanbul, Turkey, pp.187-193.

Hristov, Neno. (2017d). Policy for Implementation of the Enterprise Architecture as a Tool in Bulgarian Mod. // The University of Sydney, 'History, Problems and Prospects of Development of Modern Civilization' The XX International Academic Congress (Australia, Sydney, 18-20 July 2017) Papers and commentaries Volume XX, ISBN: 978-0-578-84563-7, pp. 821-829.

Madanski, V., Georgiev, M. (2017e). The offset as a specific sort of economic activity. // Scientific journal «Economics and finance». Academic publishing house of the Agricultural University, Priority research areas: Collection of scientific articles, 2017, pp. 4-13, ISBN 978-617-7214-53-2.

Madanski, V., Georgiev, M. (2017f). Study of the effect of offset implementation on technology transfer in the Republic of Bulgaria. // Scientific journal «Economics and finance». Academic publishing house of the Agricultural University, Priority research areas: Collection of scientific articles, 2017, pp. 43-51, ISBN 978-617-7214-53-2.

Terziev, V., Madanski, V., Georgiev, M. (2017g). Offset as an economic operation and a trade practice. // Proceedings of ADVED 2017- 3rd International Conference on Advances in Education and Social Sciences 9-11 October 2017- Istanbul, Turkey. International Organization Center of Academic Research, www.ocerint.org, 2017, pp. 748-753, ISBN: 978-605-82433-0-9.

Terziev, V., Madanski, V., Georgiev, M. (2017h). Offset implementation impact on technology transfer in Bulgaria. // Proceedings of ADVED 2017- 3rd International Conference on Advances in Education and Social Sciences 9-11 October 2017- Istanbul, Turkey .International Organization Center of Academic Research, www.ocerint.org, 2017, pp. 743-747, ISBN: 978-605-82433-0-9.

Terziev, V., Madanski, V., Georgiev, M. (2017i). Offset implementation impact on technology transfer in Bulgaria. // IJAEDU- International E-Journal of Advances in Education, International Organization Center of Academic Research, www.ocerint.org, 3, 2017, N 9, pp. 923-927, e-ISSN: 2411-18.

Terziev, V., Madanski, V., Georgiev, M. (2017j). Offset as an economic operation and a trade practice. // IJAEDU- International E-Journal of Advances in Education, International Organization Center of 
Academic Research, www.ocerint.org, 3, 2017, N 9, pp. 1051-1055, e-ISSN: 2411-18.

Terziev, V., Nichev, N., Bankov, S. (2016a). Corruption and national security. // Mezhdunarodnyy nauchnnyy zhurnal Inovatsionnaya nauka, №10-3/2016, Chastyakh 3, Ufa, Rossiya, ISSN 2410-6070, s.189-196 (Terziev, V., Nichev, N., Bankov, S. Corruption and national security. // Международный научнный журнал Иновационная наука, №10-3/2016, Частях 3, Уфра, Россия, ISSN 2410-6070, с.189-196).

Terziev, V., Nichev, N., Bankov, S. (2016b). Essence and reasons for the manifestation and basic areas of corruption and government structures for corruption counteraction in Bulgaria. // Sbornik nauchnykh trudov „Novyy vzglyad”: Mezhdunarodnyy nauchnyy vestnik: sbornik nauchnykh trudov. Vypusk 15 / Pod obshch. red. S.S. Chernova. - Novosibirsk: Izdatel'stvo TSRNS, 2016. - 166 s., ISBN 978-500068-714-7, s.116-134 (Terziev, V., Nichev, N., Bankov, S. Essence and reasons for the manifestation and basic areas of corruption and government structures for corruption counteraction in Bulgaria. // Сборник научных трудов „Новый взгляд”: Международный научный вестник: сборник научных трудов. Выпуск 15 / Под общ. ред. С.С. Чернова. - Новосибирск: Издательство ЦРНС, 2016. - 166 c., ISBN 978-5-00068-714-7, c.116-134).

Terziev, V., Nichev, N., Bankov, S. (2016c). National security of the republic of Bulgaria. // Science and practice: Collection of scientific articles. Thoroe-Bowker, Melbourne, Australia, 2016, ISBN 978-09942661-3-2, pp.12-21.

Terziev, V., Nichev, N., Bankov, S. (2016d). Tipichni modeli na razsledvanena koruptsiyata sred politseyski sluzhiteli. // Sbornik dokladi: Godishna universitetska nauchna konferentsiya, 20-21 oktomvri 2016 g., NVU „Vasil Levski“ - Veliko Tarnovo., Nauchno napravlenie „Sotsialni, stopanski i pravni nauki“, 7, 2016, ISSN 1314-1937, str.119-128 (Терзиев, В., Ничев, Н., Банков, С. Типични модели на разследванена корупцията сред полицейски служители. // Сборник доклади: Годишна университетска научна конференция, 20-21 октомври 2016 г., НВУ „Васил Левски“ - Велико Търново., Научно направление „Социални, стопански и правни науки“, 7, 2016, ISSN 1314-1937, стр.119-128).

Terziev, V., Nichev, N., Bankov, S. (2016e). Nakazatelno pravni aspekti na koruptsiyata i ustanoveni praktiki v Balgariya. // Sbornik dokladi: Godishna universitetska nauchna konferentsiya, 20-21 oktomvri 2016 g., NVU „Vasil Levski“ - Veliko Tarnovo., Nauchno napravlenie „Sotsialni, stopanski i pravni nauki“, 7, 2016, ISSN 1314-1937, str.129-146 (Терзиев, В., Ничев, Н., Банков, С. Наказателно правни аспекти на корупцията и установени практики в България. // Сборник доклади: Годишна университетска научна конференция, 20-21 октомври 2016 г., НВУ „Васил Левски“ - Велико Търново., Научно направление „Социални, стопански и правни науки“, 7, 2016, ISSN 1314-1937, стр.129-146).

Terziev, V., Nichev, N., Bankov, S. (2016f). Prilozhenie na efektivna metodika na razsledvane na koruptsiyata sred politseyskite sluzhiteli v Balgariya. // Godishnik na NVU „Vasil Levski“, NVU „Vasil Levski“- Veliko Tarnovo, Izdatelski kompleks na NVU „Vasil Levski”, 2015, ISSN 1312-6148, str.144185 (Терзиев, В., Ничев, Н., Банков, С. Приложение на ефективна методика на разследване на корупцията сред полицейските служители в България. // Годишник на НВУ „Васил Левски“, НВУ „Васил Левски“- Велико Търново, Издателски комплекс на НBУ „Васил Левски”, 2015, ISSN 1312-6148, стр.144-185).

Terziev, V., Nichev, N., Bankov, S. (2016g). Razrabotvane na metodika na razsledvane na koruptsiyata sred politseyskite sluzhiteli v Balgariya. II XI Mezhdunarodnoy nauchnoy konferentsii "Innovatsii v tehnologiyah i obrazovanii“, 18-19 Marta 2016 g., Sbornik statey: chasty 3, Belovo- Veliko-tayrnovo, 2016, Kuzbasskiy gosudarstvennayy tehnicheskiy universitet imeni T.F. Gorbacheva Velikotayrnovskiy universitet im. Svyatayh. Kirilla i Mefodiya Filial KuzGTU v g. Belovo Vaysshaya shkola agrobiznesa i razvitiya regionov, Plovdiv, 2016, s.413-422, ISBN 978-5-906888-03-7 (Терзиев, В., Ничев, Н., Банков, С. Разработване на методика на разследване на корупцията сред полицейските служители в България. // XI Международной научной конференции „Инновации в технологиях и образовании“, 18-19 Марта 2016 г., Сборник статей: часть 3, Белово- Велико-тырново, 2016, Кузбасский государственный технический университет имени Т.Ф. Горбачева Великотырновский университет им. Святых. Кирилла и Мефодия Филиал КузГТУ в г. Белово Высшая школа агробизнеса и развития регионов, Пловдив, 2016, с.413-422, ISBN 978-5-906888-03-7).

Terziev, V., Nichev, N., Bankov, S. (2016h). Prilozhenie na efektivna metodika na razsledvane na koruptsiyata sred politseyskite sluzhiteli v Balgariya. // Sbornik dokladi: Parva nauchna konferentsiya po sotsialno predpriemachestvo. Saveti, umeniya i instrumenti za konsultirane na sotsialnite predpriemachi, Proekt : Umeniya za biznes konsultanti v oblastta na sotsialnoto predpriemachestvo, 
International scientific conference 29 September 2016, Plovdiv, Bulgaria, Agraren Universitet Plovdiv, 2016, ISBN 978-954-517-249-6 (CD), ISBN 978-954-517-250-2 (Print), str.177-204 (Терзиев, В., Ничев, Н., Банков, С. Приложение на ефрективна методика на разследване на корупцията сред полицейските служители в България. // Сборник доклади: Първа научна конференция по социално предприемачество. Съвети, умения и инструменти за консултиране на социалните предприемачи, Проект : Умения за бизнес консултанти в областта на социалното предприемачество, International scientific conference 29 September 2016, Plovdiv, Bulgaria, Аграрен Университет Пловдив, 2016, ISBN 978-954-517-249-6 (CD), ISBN 978-954-517-250-2 (Print), стр.177-204).

Nichev, N. (2017k). Ofsetna politika na stranite ot Evropeyskiya Sayuz. Spisanie za nauka „Novo znanie”, Akademichno izdatelstvo „Talant“, Visshe uchilishte po agrobiznes i razvitie na regionite, Plovdiv, Vol 6, No 1, 2017, str. 121-128, ISSN 2367-4598 (Online), ISSN 1314-5703 (Print) (Ничев, Н. Офрсетна политика на страните от Европейския Съюз. Списание за наука „Ново знание”, Академично издателство „Талант“, Висше училище по агробизнес и развитие на регионите, Пловдив, Vol 6 , No 1, 2017, стр. 121-128, (Online) ISSN 2367-4598, (Print) ISSN 1314-5703).

Nichev, N. (2017l). Perspektivi za izpolzvane na ofsetnite sdelki. Spisanie za nauka „Novo znanie”, Akademichno izdatelstvo „Talant", Visshe uchilishte po agrobiznes i razvitie na regionite - Plovdiv, Vol 6, No 1, 2017: pp. 129-135, (Online) ISSN 2367-4598, (Print) ISSN 1314-5703 (Ничев, Н. Перспективи за използване на офсетните сделки. Списание за наука „Ново знание”, Академично издателство „Талант“, Висше училище по агробизнес и развитие на регионите Пловдив, Vol 6, No 1, 2017: pp. 129-135, (Online) ISSN 2367-4598, (Print) ISSN 1314-5703).

Kanev, D.,Terziev. V. (2017m). Behavioral economics: development, condition and perspectives. // IJASOSInternational E-Journal of Advances in Social Sciences, Vol. III, Issue 8, e-ISSN: 2411-183X.

Kanev, D.,Terziev. V. (2017n). Behavioral economics: development, condition and perspectives. // Proceedings of SOCIOINT 2017- 4th International Conference on Education, Social Sciences and Humanities 10-12 July 2017- Dubai, UAE, ISBN: 978-605-82433-1-6.

Sotirov, B., Terziev, V. (2015a). Predizvikatelstva i perspektivi pred obuchenieto po tehnologichni distsiplini. // Parva mezhdunarodna nauchna konferentsiya „Predizvikatelstva pred savremennite organizatsii, svarzani s postigane na ustoychivost - znanie i inovatsii v upravlenieto i funktsioniraneto",Plovdiv. ISBN 978-619-7246-04-9 (DVD), ISBN 978-619-7246-06-3 (e-book).

Sotirov, B., Terziev, V. (2015b). Challenges and perspectives to the training in technological subjects. // Book of Abstracts: First International Scientific Conference "Sustainability Challenges in Modern Organizations - Knowledge \& Innovation in Management \& Operation", ISBN 978-619-7246-03-2 (DVD), ISBN 978-619-7246-05-6 (e-book).

Terziev. V. (20170). National security of the republic of Bulgaria. // The Chinese Journal of International Politics, №1(10), ISSN 1750-8916.

Terziev. V. (2016i). Human resource management systems in security and defense: social policies for social activities. // XXXII Mezhdunarodnaya nauchno-prakticheskaya konferentsiya, Evraziyskiy soyuz uchenayh (ESU), Ezhemesyachnayy nauchnayy zhurnal № 12 (33)/ 2016 Chasty 1, Moskva 30.12.2016g., ISSN 2411-6467.

Terziev. V. (2017p). Entry Opportunities in the Bulgarian Military - Educational System and Ensuring of Civil Rights. // 3rd Central and Eastern European LUMEN International Scientific Conference New Approaches in Social and Humanistic Sciences 8-10 June 2017 | Chisinau, Republic of Moldova, ISBN: 978-973-166-461-3.

Terziev. V. (2017q). National security of the republic of Bulgaria. // International Journal of Management and Applied Science, Volume-3, Issue-4, ISSN: 2394-7926.

Terziev, V., Vezieva. V., Arabska, A. (2016j). Balgarskite universiteti i vazmozhnostite na Operativna programa „Nauka i obrazovanie za inteligenten rastezh". // Mezhdunarodna nauchna konferentsiya „Obrazovanie, nauka, ikonomika i tehnologii“ 23-24 yuni 2016 g. Akademichno spisanie „Upravlenie i obrazovanie“" Tom XII(1) 2016, ISSN 1312-6121.

Terziev, V., Manolov.D. (2016k). Sazdavane na dobra organizatsionna sreda za nauchnoizsledovatelska deynost (Creation of good organizational environment for scientific research activity), Aktual'nyye problemy globalizatsii. // Saloniki, Gretsiya (Actual problems of globalization, August 29, 2016, Thessaloniki, Greece), Scientific journal „ECONOMICS AND FINANCE“, Actual problems of 
globalization - Collection of scientific articles, ISBN 978-617-7214-34-1.

Terziev, V., Minev, R., Sotirov, B., Ivanov, K. (2016I). Vazmozhnosti za izgrazhdane na tsentar za kompetentnost $v$ Severen tsentralen rayon na Republika Balgariya. // Godishna universitetska nauchna konferentsiya, 20-21 oktomvri 2016 g. NVU „Vasil Levski“- Veliko Tarnovo. Sbornik dokladi tom 2, Nauchni napravleniya „Prirodomatematicheski nauki” i „Tehnicheski nauki”, ISSN 1314-1937.

Terziev. V., Kanev, D. (2017r). Education and Behavioural Failures. // Proceedings of ADVED 2017- 3rd International Conference on Advances in Education and Social Sciences 9-11 October 2017- Istanbul, Turkey, ISBN: 978-605-82433-0-9.

Terziev, V, Madanski, V. (2017s). Development of military education system in Bulgaria (Razvitie na voennoobrazovatelnata sistema $\vee$ Balgariya). // Topical questions of contemporary science, United States of America 2017, ISBN 978-0-9988732-1-3.

Terziev, V, Madanski, V. (2017t). Guidelines for development of military education system in Bulgaria (Nasoki za razvitie na voennoobrazovatelnata sistema na Balgariya). // Topical questions of contemporary science, United States of America 2017, ISBN 978-0-9988732-1-3.

Terziev, V, Madanski, V. (2017u). Guidelines for development of military education system in Bulgaria. // Proceedings of the VII International Academic Congress "Fundamental and Applied Studies in EU and CIS Countries" (United Kingdom, Cambridge, England, 26-28 February 2017). Volume VII. Cambridge University Press, 2017, ISBN: 978-0-875-83597-4.

Terziev, V, Madanski, V., Kanev, D. (2017v). Entry opportunities in the bulgarian military-educational system and ensuring of civil rights. // Proceedings of SOCIOINT 2017- 4th International Conference on Education, Social Sciences and Humanities 10-12 July 2017- Dubai, UAE, ISBN: 978-605-82433-1-6.

Terziev, V, Madanski, V., Kanev, D. (2017w). Entry opportunities in the bulgarian military-educational system and ensuring of civil rights. // IJAEDU- International E-Journal of Advances in Education, Vol. 3, Issue 8, August 2017, e-ISSN:2411-1821.

Terziev, V, Madanski, V., Kanev, D. (2017x). Entry opportunities in the Bulgarian military-educational system. // Sport, Education and Society, Issue 8 (2), Volume 22. Taylor \& Francis, Print ISSN: 1357-3322 Online ISSN: 1470-1243.

Terziev, V, Madanski, V., Kanev, D. (2017y). Condition and capabilities of the military-educational system of the Republic of Bulgaria. // Sport, Education and Society, Issue 8 (2), Volume 22. Taylor \& Francis, Print ISSN: 1357-3322 Online ISSN: 1470-1243.

Terziev, V, Madanski, V., Kanev, D. (2017z). Directions for improvement of the military-educational system and its contribution for strengthening national security and the defence of the country. // Sport, Education and Society, Issue 8 (2), Volume 22. Taylor \& Francis, Print ISSN: 1357-3322 Online ISSN: 1470-1243.

Terziev, V., N.Nichev. (2016m). Ikonomicheski harakteristiki na ofestnite sdelki s otrbranitelni produkti. // Scientific journal „Economics and Finance”, Problems of development modern science: Theory and practice - Collection of scienfic articles, pp.101-106.

Terziev. V., N.Nichev. (2017). Osnovni harakteristiki na kompensaciite $v$ tyrgoviqta s otbrana. // Proceedings of SOCIOINT 2017- 4th International Conference on Education, Social Sciences and Humanities, pp.661-666. 